\title{
Ability Analysis of Pedagogical Content Knowledge of Prospective Teacher Students Majoring in Mathematics
}

\author{
Ruslan*, Sahid, \& Nurul Ilmi Pratiwi \\ Department of Mathematics, Universitas Negeri Makassar, Makassar, Sulawesi Selatan, Indonesia
}

\begin{abstract}
This research is a qualitative research that aims to determine the Pedagogical Content Knowledge of prospective teacher students majoring in mathematics at the State University of Makassar. The research subjects consisted of 3 student teacher candidates majoring in mathematics in the sixth semester. The subject-taking technique in this study amounted to three student teacher candidates majoring in mathematics with a cumulative achievement index of less than 3.00 and $3.01-3.50$ and $3.51-4.00$. The instruments in this study used CoRe, PaP-eRs, and Vignette. Data collection techniques in this study are observations based on PCK indicators and giving the Vignette test. The data analysis technique uses the Miles and Huberman model, namely data reduction, data presentation, and conclusions. Based on the results of the study, it shows that the pedagogical knowledge aspects of most of the points in CoRe are fulfilled. Then for the content knowledge aspect, the subject with an achievement index of $3.50-$ 4.00 is at level 1 , an achievement index of $3.00-3.50$ is at level 0 and an achievement index of less than 3.00 is at level 2.
\end{abstract}

Keywords: pedagogical content knowledge, students, mathematics, teacher candidate.

\section{Introduction}

Pendidikan yang berkualitas sangat dipengaruhi oleh guru yang berkualitas. Dengan kata lain, hanya guru yang berkualitas yang mampu meningkatkan kualitas pendidikan. Guru adalah pendidikan profesional yang memerlukan kemahiran, keahlian dan kecakapan minimal memenuhi kompetensi dan standar tertentu. Guru harus memiliki pengetahuan yang mendalam tentang bagaimana cara mengajarkan materi yang biasa disebut pengetahuan pedagogik (pedagogical knowledge). Bukan hanya itu saja pastilah seorang guru pun harus memiliki pendalaman materi yang akan diajarkan kemampuan ini biasa disebut content knowledge. Banyak yang beranggapan jika seorang guru pendalaman materinya baik maka pasti dapat mengajar dengan baik. Hal ini belum tentu dapat tercapai karena jika seorang guru tidak memiliki pengetahuan pedagogik, maka hasil pembelajaran pun akan sulit tercapai.

Perpaduan antara pemahaman dan pengetahuan akan cara mengajar yang baik dapat menunjang keberhasilan dalam proses pembelajaran sehingga perpaduan ini biasanya disebut pengetahuan konten pedagogik (Pedagogical Content Knowledge). Calon guru harus di bekali dengan kemampuan mengajar yang mempunyai keterampilan-ketrampilan yang mampu mempermudah siswa dalam pembelajaran. Keterampilan-keterampilan tersebut di antaranya adalah mampu memanfaatkan media, lingkungan kelas, lembar kerja siswa dan mengaitkan karakter ke dalam pembelajaran (Santosa, Kusumaningsih, \& Endahwuri, 2019)

Penelitian Maryono (2016) mengungkapkan bahwa kenyataan di lapangan menunjukkan bahwa guru matematika secara umum bisa dikategorikan ke dalam 4 kelompok, yaitu: (1) guru dengan pengetahuan konten dan pengetahuan pedagogis yang baik; (2) guru dengan pengetahuan konten baik, tetapi mempunyai pengetahuan pedagogis yang kurang; (3) guru dengan pengetahuan konten kurang, tetapi mempunyai pengetahuan pedagogis yang baik; dan (4) guru dengan pengetahuan konten dan pengetahuan pedagogis yang kurang. Idealnya seorang guru harus masuk ke dalam kelompok (1), tetapi kenyataannya banyak yang belum bisa dikategorikan ke dalam kelompok tersebut. (Uyun, 2019).

\footnotetext{
* Corresponding author.

E-mail address: ruslan_math_unm@yahoo.com (Ruslan)
} 
Dalam pendidikan sebaiknya seorang guru memiliki kemampuan kompetensi PCK untuk mengelola pembelajaran yang akan dilakukan oleh peserta didik dan juga akan menentukan tingkat keberhasilan proses serta hasil pembelajaran peserta didik. Oleh karena itu guru semestinya meningkatkan kemampuan dan potensinya dalam PCK karena akan sangat membantu dalam penentuan keberhasilan dalam proses pembelajaran. Sehingga untuk menghasilkan calon guru yang berkualitas adalah harapan untuk memajukan pendidikan terutama dalam matematika. Penelitian ini bertujuan untuk mengetahui bagaimana gambaran kemampuan PCK mahasiswa calon guru matematika di FMIPA Universitas Negeri Makassar.

\section{Literature Review}

Pedagogical Knowledge mendeskripsikan tujuan umum kekhasan pengetahuan untuk mengajar. Hal tersebut merupakan kumpulan keterampilan yang guru harus kembangkan supaya mampu mengelola dan mengorganisasikan pengajaran dan aktivitas pembelajaran untuk mencapai tujuan pembelajaran yang diharapkan. Pengetahuan ini meliputi (namun tidak terbatas pada) pemahaman aktivitas pengelolaan kelas, peran motivasi siswa, rencana pembelajaran, dan penilaian pembelajaran. Pengetahuan pedagogik merupakan jenis pengetahuan yang unik untuk guru dan didasarkan pada cara guru dalam mengajarkan apa yang akan diajarkan (Aminah 2013). Pedagogical Knowledge juga mendeskripsikan pengetahuan dari metode mengajar yang berbeda-beda meliputi pengetahuan untuk mengetahui bagaimana mengorganisasikan aktivitas di kelas agar kontruksi pengetahuan siswa (pembelajaran) kondusif (Rosyid, 2016).

Pengetahuan konten yang kuat dari seorang guru, akan memberikan pengaruh yang positif pada pembuatan keputusan yang berhubungan dengan perubahan strategi mengajar. (Iriani, 2018). Hal ini dimaksudkan untuk menciptakan kesempatan belajar yang lebih baik. Content Knowledge merupakan salah satu pengetahuan yang ada di dalam PCK.

Terdapat beberapa penelitian yang berkaitan dengan pedagogical content knowledge mahasiswa calon guru (Anwar, 2016; Aminah, 2014; Agustina, 2015; Mampouw, 2011; Bahari, 2020). Agustina (2015) dalam penelitiannya mengungkapkan bahwa PCK merupakan pengetahuan yang harus dipahami oleh seorang guru dan calon guru karena seorang guru harus familiar dengan konsep alternatif dan kesulitan yang akan dihadapi siswa yang beragam latar belakang serta dapat mengorganisasikan, menyusun, menjalankan dan menilai materi subjek, yang semuanya itu terangkum dalam PCK. Selain itu, Anwar (2016) mengungkapkan bahwa PCK juga meliputi pendekatan apa yang sesuai dengan konten atau dapat juga bagaimana elemen konten dapat diatur untuk pembelajaran yang lebih baik.

PCK penting untuk dipahami dalam proses pengembangan science literacy dan kemampuan mentransformasi pengetahuan pendidik ke dalam proses pembelajaran. Selain itu pentingnya PCK bagi seorang pendidik karena dapat menciptakan pembelajaran yang bermanfaat untuk peserta didik. (Margiyono \& Mampouw 2011).

PCK dipandang sebagai perpaduan antara pengetahuan seorang guru dalam menguasai isi materi ajar dan pedagogik dalam memahami suatu masalah, topik yang disesuaikan dengan minat dan kemampuan siswa yang efektif untuk topik khusus, seperti pemahaman tentang cara membuat topik khusus itu mudah atau sulit untuk dipelajari (Fuadi, et.al, 2018)

\section{Research Methods}

Penelitian ini merupakan penelitian kualitatif dengan pendekatan deskriptif. Penelitian dilaksanakan di jurusan matematika Fakultas Matematika Ilmu Pengetahuan Alam Universitas Negeri Makassar. Subjek dalam penelitian ini terdiri dari 3 orang mahasiswa yang dikelompokkan kedalam masing-masing tingkat kemampuan akademik yaitu 1 mahasiswa dengan kemampuan akademik pujian, (IPK $\geq 3,50), 1$ mahasiswa dengan kemampuan akademik sangat memuaskan ( $3,01 \leq I P K \leq 3,50)$, dan 1 mahasiswa dengan kemampuan akademik memuaskan $(2,76 \leq I P K \leq 3,00)$. Instrumen pendukung penelitian yang digunakan dalam penelitian ini adalah CoRe, PaP-eRs, dan Vignette. Seluruh instrumen tersebut masing-masing divalidasi oleh dua orang ahli. Pedagogical content knowledge menyebutkan dua elemen untuk mengeksplorasi dan menginterpretasikan yaitu menggunakan CoRe dan PaP-eRs.

CoRe merupakan suatu tabel yang merepresentasikan pemahaman materi guru pada topik tertentu. Dari uraian CoRe yang dikembangkan oleh Loughran dkk tersebut untuk keperluan penelitian, peneliti mengembangkan CoRe 1 menjadi sebagai berikut: 


\section{CoRe 1}

1) Apa kesulitan Anda dalam mengajarkan materi ini kepada siswa?

2) Strategi apa yang Anda gunakan dalam mengajarkan materi ini kepada siswa dan mengapa Anda menggunakan strategi tersebut?

3) Dengan strategi ini apakah Anda dapat mengetahui sejauh mana pemahaman siswa, kesulitan siswa mengenai materi ini, serta miskonsepsinya?

4) Setelah strategi ini diterapkan apa kelebihan dan kelemahannya?

5) Apa yang Anda lakukan untuk mengatasi kesulitan siswa dan miskonsepsinya?

Berdasarkan CoRe yang dikembangkan oleh Maryati tersebut, peneliti mereduksi CoRe menjadi sebagai berikut:

1) Penyampaian tujuan pembelajaran

2) Memiliki tujuan pembelajaran yang jelas, sesuai dengan kurikulum

3) Memiliki pengetahuan terhadap konten materi yang akan dibelajarkan

4) Menerapkan strategi pembelajaran yang mendukung ketecapaian tujuan pembelajaran

5) Menyampaikan pertanyaan dalam menyelidiki kesulitan siswa

6) Menerapkan strategi pembelajaran untuk mengatasi kesulitan siswa

7) Mengintegrasikan materi pelajaran dengan materi lain yang dapat mendukung pemahaman siswa

Pengambilan data dalam penelitian ini dimulai dengan melakukan observasi kepada mahasiswa calon guru. Observasi dalam penelitian ini disesuaikan dengan komponen dan indikator PCK pada lembar observasi, jika berkaitan dengan penyusunan perangkat pembelajaran maka yang diobservasi adalah perangkatnya, jika berkaitan dengan proses pembelajaran maka observasi dilakukan dengan mengamati video pembelajaran yang telah disusun oleh subjek penelitian. Untuk instrumen vignette peneliti akan memberikan soal kepada mahasiswa lain yang bertindak sebagai siswa untuk menyelesaikan soal tersebut. Selanjutnya soal tersebut diberikan kepada subjek untuk kemudian dikomentari mengenai hasil jawaban tersebut. Selanjutnya wawancara pada penelitian ini dilakukan dengan menggunakan pedoman wawancara yaitu CoRe I dan menggunakan wawancara semistruktur kepada subjek yang telah terpilih menjadi subjek wawancara. Adapun metode yang digunakan dalam analisis data menurut Miles and Huberman yang meliputi kondensasi data, penyajian data, serta penarikan atau verifikasi kesimpulan.

\section{Results and Discussion}

\subsection{Subjek Tinggi (ST)}

Subjek mengucapkan salam, memimpin doa sebelum memasuki pelajaran serta subjek memperkenalkan dirinya terlebih dahulu. Kemudian subjek menyampaikan tujuan pembelajaran secara lengkap seperti yang subjek tuliskan di RPPnya. Subjek memulai pelajaran dengan mengintegrasikan bentuk aljabar sebelum memasuki pelajaran inti.

\section{Transkrip 1}

$P \quad \quad$ : Strategi apa yang anda gunakan untuk mengajarkan materi ini kepada siswa?

ST-101 : Strategi atau modelnya saya menggunakan ekspositori

$P \quad$ :Kenapa anda menggunakan ekspositori dalam video pembelajarannya?

ST-102 : Dalam ekspositori itu ada ceramah dan bertanya, dan saya rasa strategi itu cocok kalau dipakai itu model ekspositori apalagi siswa SMP yang diajar kak kalau hanya ceramah saja yang digunakan nanti pasti cepat merasa bosan dan mengantuk.

Berdasarkan Transkrip 1, subjek menggunakan strategi ekspositori alasannya karena strategi tersebut tidak hanya ceramah yang membuat siswa mudah bosan tetapi juga dengan bertanya (ST-102). Hal tersebut menunjukkan bahwa subjek telah menerapkan strategi pembelajaran berdasarkan RPP yang disusun.

Selanjutnya, subjek menjelaskan mengenai perbedaan dari persamaan dan pertidaksamaan linear satu variabel serta memberikan contohnya, tetapi tidak dijelaskan bagaimana menentukan penyelesaian pertidaksamaannya. Hasil wawancara peneliti dengan subjek menunjukkan bahwa subjek memang tidak menyampaikan penyelesaiannya dari sistem permasalahan yang diberikan. Berikut petikan wawancara tersebut pada Transkrip 2: 


\section{Transkrip 2}

P $\quad$ : Tadi yang anda jelaskan hanya penyelesaian persamaan satu variabel kan? Anda tidak jelaskan bagaimana penyelesaian pertidaksamaannya?

ST-201 : Ohiya kak saya lupa

P : Kenapa? Padahal di RPP anda kamu menuliskan bahwa menentukan penyelesaian pertidaksamaan linear satu variabel

ST-202 : Iya kak saya lupa

Transkrip 2 menunjukkan bahwa subjek memang tidak membahas mengenai penyelesaian pertidaksamaan linear satu variabel dikarenakan lupa (S1-201). Hal ini menunjukkan bahwa dalam penyampaian materi, subjek kurang menguasai materi yang akan disampaikan.

Sebelum mengakhiri pembelajaran subjek memberikan Latihan soal untuk dikerjakan oleh siswa dirumah. Ini merupakan salah satu cara subjek untuk mengevaluasi kembali hasil pembelajaran yang telah diberikan oleh subjek. Kemudian subjek mengakhiri video pembelajarannya dengan memberikan kata-kata motivasi buat siswa dan mengucapkan salam.

Selanjutnya content knowledge subjek tinggi, karakteristik pengetahuan konten pada level 1 yaitu: menyatakan definisi dengan tepat, menggunakan notasi dengan tepat, masih menggunakan pertanyaan deklaratif atau prosedural, menginterpretasikan dan menggunakan representasi grafik dan selain grafik, dan melihat koneksi antara topik/ subunit berbeda. Hal ini bisa dilihat pada jawaban subjek terlihat pada gambar 1.

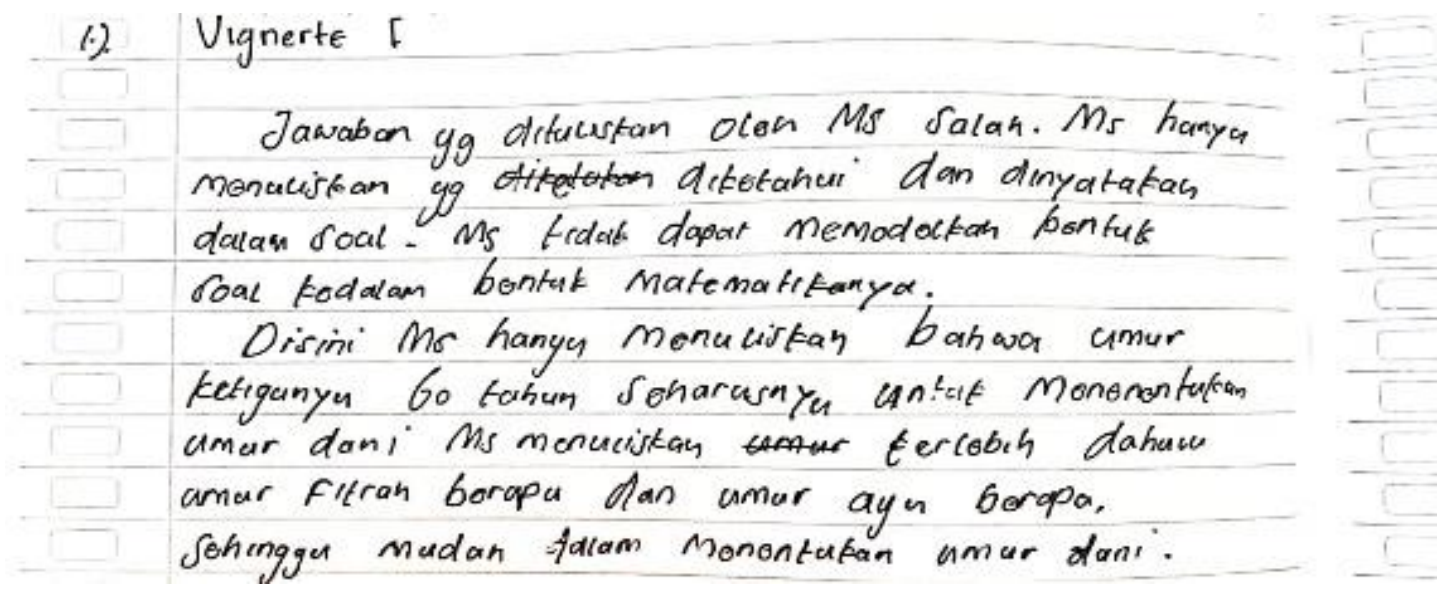

Gambar 1. Komentar ST Soal No. 1

Selain itu, juga dapat dilihat dari Transkrip 3 berikut:

\section{Transkrip 3}

$P \quad$ : untuk yang dituliskan oleh MS apakah sudah betul dalam menentukan apa yang diketahui dalam soal?

ST-301 : Tidak kak

$P \quad$ : Menurut anda bagian mana yang salah dari yang dituliskan oleh MS?

ST-302 : Berdasarkan yang dituliskan oleh MS kak dia tidak mengetahui sama sekali mengenai materi persamaan dan pertidaksamaan linear, buktinya dia tidak bisa memisalkan variabel berdasarkan apa yang diketahui dari soal

$P \quad$ : Jadi kalau misalkan anda dapat soal seperti ini bagaimana cara anda memodelkan soal tersebut kedalam bentuk matematika?

ST-303 : Pertama kita misalkan terlebih dahulu apa yang menjadi variabelnya setelah itu kita lihat redaksi soalnya, apakah soal tersebut termasuk kedalam persamaan atau pertidaksamaan. Selanjutnya berdasarkan dari soal tersebut kita sudah bisa memodelkan soalnya kedalam bentuk satu linear

P $\quad$ : Menurut anda bagaimana model matematika yang benar pada soal tersebut? apakah soal tersebut termasuk ke dalam persamaan atau pertidaksamaan? 
Transkrip 3 menunjukkan bahwa subjek mengetahui dengan baik konsep mengenai persamaan dan pertidaksamaan linear satu variabel berdasarkan dari jawaban yang diberikan subjek kepada peneliti yang menjelaskan bahwa soal tersebut termasuk kedalam salah satu contoh soal persamaan linear satu variabel (ST-304). Hal ini menunjukkan bahwa subjek mampu mengungkapkan definisi dengan benar. Namun subjek masih bingung dalam menentukan soal tersebut termasuk ke dalam persamaan atau pertidaksamaan. Dapat disimpulkan bahwa pada masalah ini pengetahuan konten subjek berada pada level 1.

\subsection{Subjek Sedang (SS)}

Pada awal kegiatan pembelajaran, subjek mengucapkan salam, setelah itu subjek memimpin doa sebelum memulai pelajaran dan memperkenalkan dirinya. Subjek sudah memenuhi tujuan pembelajaran dengan kurikulum yang ada tetapi subjek tidak menyampaikan tujuan pembelajaran secara mendetail.

Pada kegiatan inti subjek menjelaskan tentang materi bentuk aljabar sebelum memasuki materi persamaan dan pertidaksamaan linear satu variabel. Subjek terkesan tergesa-gesa dan gugup dalam kegiatan pembelajaran serta berbagai latihan soal pun yang sudah dituliskan juga tidak dibahas, padahal contoh soal tersebut salah satu hal yang sangat penting agar siswa dapat paham konsep dalam materi persamaan dan pertidaksamaan linear satu variabel. Pada kegiatan pembelajaran subjek menggunakan strategi CTL dapat dilihat pada Transkrip 3:

\section{Transkrip 4}

$\begin{array}{ll}P & \text { : Kenapa harus CTL yang anda pilih untuk pembelajaran secara virtual? } \\ \text { SS-401 } & \text { : Karena materinya kan tentang persamaan dan pertidaksamaan linear satu variabel nah } \\ & \text { didalam materi itu kebanyakan kita membahas tentang kehidupan sehari-hari. Dan didalam } \\ & \text { CTL setahu saya kak salah satu tujuannya itu kita dapat menghubungkan permasalahan dalam } \\ & \text { kehidupan nyata dengan materi persamaan dan pertidaksamaan linear satu variabel. Makanya } \\ & \text { saya rasa itu sangat cocok kalo kita terapkan strategi CTL” } \\ & : \text { Menurut anda kalau kita terapkan strategi ini kita bisa mengetahui sejauh mana } \\ & \text { pemahamannya siswa? } \\ \text { SS-402 } & \text { : Bisa kak, karena menurut saya sekarang kan pembelajaran online dan yang paling penting itu } \\ & \text { kita sebagai guru harus bisa dulu membangun pemahaman konsepnya siswa tentang materi } \\ & \text { yang akan kita ajarkan kak }\end{array}$

Transkrip 4 menunjukkan bahwa, alasan subjek menggunakan strategi CTL karena siswa perlu memahami konsep untuk menyelesaikan soal cerita agar dapat mengetahui permasalahan sehari-hari dengan materi persamaan dan pertidaksamaan linear satu variabel (SR-401). Hal tersebut menunjukkan bahwa subjek 2 ingin siswa yang diajarnya dapat mengkonstruksi pemahamannya terlebih dahulu mengenai konsep pada materi persamaan dan pertidakamaan linear satu variabel (SR-402)

Pada akhir pembelajarannya subjek menanayakan kembali apakah masih ada siswa yang belum paham terhadap soal yang diberikan sebelumnya, dan semua siswa menjawab sudah paham. Kemudian subjek mengakhiri pembelajaran dengan berdo'a dan salam.

Selanjutnya konten pada subjek, untuk subjek dengan kemampuan akademik baik, pengetahuan tentang kontennya sama dengan kelompok mahasiswa calon guru kemampuan sangat baik, yaitu Sebagian besar berada pada level 0 . Misalnya pada masalah ini subjek masih kurang yakin untuk mengungkapkan jawaban dari MS.

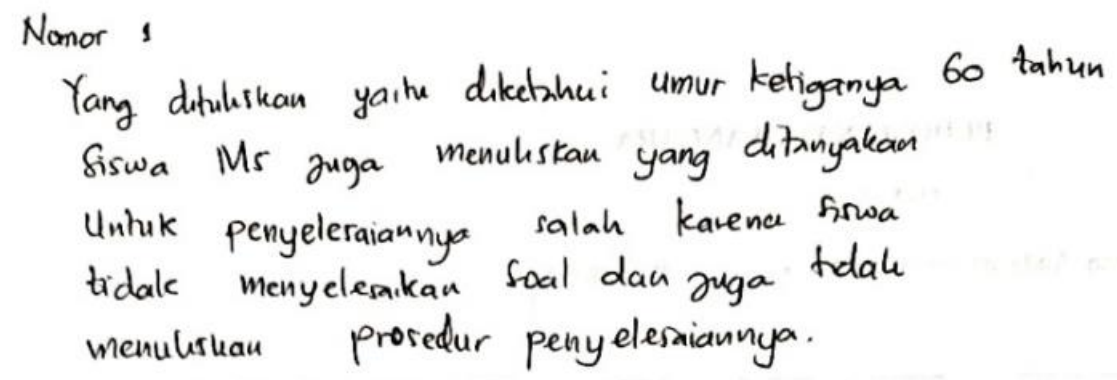

Gambar 2. Komentar SS Kasus 1 


\section{Transkrip 5}
$P$
: Jadi penyelesaian yang dituliskan oleh MS salah?
SS-501 : Iya salah"
P : Tetapi disini MS menjawab umur Dani itu 18 tahun, bagaimana menurut anda sudah benar atau tidak jawabannya?"
SS-502 :Kayaknya salah"
$P \quad$ : Terus menurut anda kenapa bisa MS langsung menjawab seperti itu?"
SS-503 : Entahlah, kayaknya dia hanya menebak supaya cepat selesai"

Transkrip 5 menunjukkan bahwa subjek masih bingung dalam menjabarkan soal cerita tentang persamaan dan pertidaksamaan linear satu variabel (SS-502). Hal ini dapat disimpulkan bahwa pengetahuan konten subjek berada pada level 0 .

\subsection{Subjek Rendah}

Subjek mengucapkan salam, setelah itu subjek memimpin doa sebelum memulai pelajaran dan kemudian subjek memperkenalkan dirinya. Subjek sudah cukup memenuhi tujuan pembelajaran dengan kurikulum yang ada Hanya alokasi waktu untuk ketiga tujuan pembelajaran tersebut adalah 6 jam pelajaran. Sehingga tidak dijelaskan untuk setiap pertemuan target pembelajaran sampai materi apa dalam bab persamaan dan pertidaksamaan linear satu variabel tersebut.

Pada kegiatan inti subjek memulai dengan memberikan serta meminta siswa untuk menganalisis maksud dari soal yang diberikan. Subjek juga mengarahkan pemahaman yang diketahui oleh siswa tersebut kedalam materi, agar siswa lebih memahami konsep awal dari materi persamaan dan pertidaksamaan linear satu variabel. Subjek menggunakan strategi yang diterapkan yaitu PBL (Problem Based Learning) seperti pada Transkip 6 dibawah ini:

\section{Transkrip 6}

$P \quad$ : Kenapa harus PBL yang anda pilih untuk pembelajaran secara virtual?

SR-601 : :Karena materinya kan tentang persamaan dan pertidaksamaan linear satu variabel nah didalam materi itu kebanyakan kita membahas tentang masalah dalam kehidupan sehari hari yang biasanya dalam bentuk soal cerita. Sehingga saya memilih PBL karena strategi tersebut yang menghubungkan antar permasalahan - permasalahan yang diangkat untuk bisa menjadi materi untuk mengajar. Tapi sekarang lumayan susah kak dalam mengajar apalagi mengajarnya secara online jadi saya juga mengalami kesulitan dalam memilih strategi yang tepat untuk di terapkan dalam proses pembelajaran seperti ini.

$P \quad:$ Menurut anda kalau kita terapkan strategi ini apakah bisa kita tahu sejauh mana pemahamannya siswa?

SR-602 : Bisa kak, kalau menurut saya kita tahu bahwa sekarang pembelajaran dilakukan secara online jadi agar siswa dapat memahami materinya, langkah paling tepat yang harus digunakan itu memberikan terlebih dahulu masalah yang sering dialami oleh siswa baru nanti siswa sendiri yang mengaitkan dengan konsep persamaan dan pertidaksamaan linear satu variabel kak.

Berdasarkan Transkrip 6 alasan menggunakan strategi tersebut karena materi persamaan dan pertidaksamaan linear satu variabel merupakan materi yang berisi tentang permasalahan sehari-hari dalam bentuk soal cerita (SR-601), sehingga siswa perlu memahami konsep untuk menyelesaikan soal cerita agar dapat mengetahui permasalahan seharihari dengan materi persamaan dan pertidaksamaan linear satu variabel (SR-602). Hal tersebut menunjukkan bahwa subjek ingin agar siswa yang diajarnya dapat mengkonstruksi pemahamannya terlebih dahulu mengenai konsep pada materi persamaan dan pertidakamaan linear satu variabel.

Pada akhir pembelajaran Subjek meminta maaf jika ada salah kata dalam menyampaikan materi pada pertemuan hari ini. Subjek mengakhiri kegiatan pembelajaran dengan menyuruh salah satu siswa untuk memimpin do'a dan subjek mengucapkan salam.

Selanjutnya content knowledge pada subjek yaitu untuk subjek mahasiswa calon guru dengan kemampuan akademik cukup berada pada level 2. Karakteristik pengetahuan konten pada level 2 yaitu menyatakan definisi dengan tepat, menggunakan notasi dengan tepat, menggunakan semua tipe pertanyaan (deklaratif, prosedural, dan kondisional) dengan posisi yang tepat, menginterpretasikan dan menggunakan representasi grafik dan selain grafik, melihat 
koneksi antara topik/sub unit berbeda dan melangkah di antara koneksi tersebut dengan cermat. Hal ini bisa dilihat pada jawaban subjek 1 terlihat pada gambar 3 .

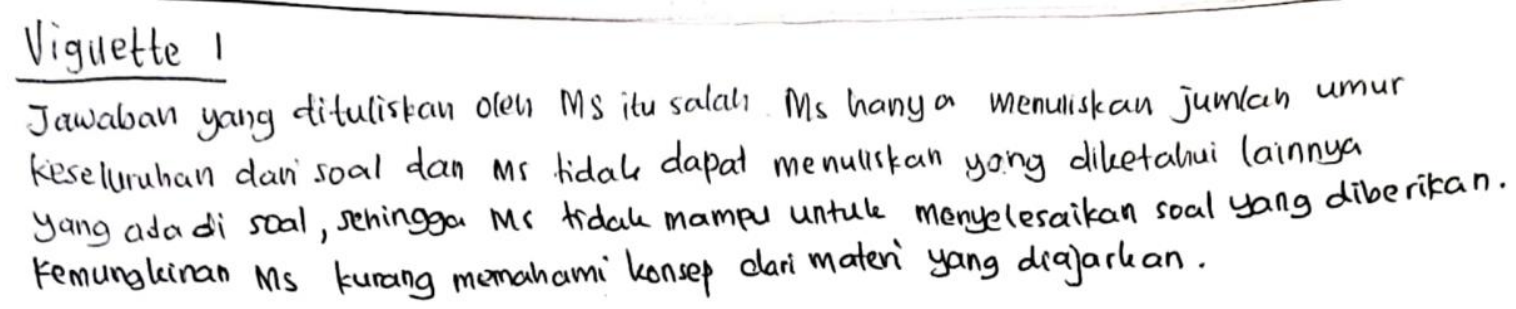

Gambar 3. Komentar SR Kasus 1

\section{Transkrip 7}
$P \quad$ : Yang dituliskan oleh MS salah?
SR-701 : Iya salah
$P \quad$ : Seharusnya bagaimana prosedur untuk penyelesain dalam soal ini?
SR-702 : Pertama, seharusnya dimisalkan terlebih dahulu apa yang jadi variabelnya dalam soal tersebut nah setelah itu kita lihat kembali soalnya, apakah soal tersebut termasuk kedalam persamaan atau pertidaksamaan kemudian berdasarkan dari soal tersebut kita sudah bisa modelkan kedalam bentuk satu linear
P $\quad$ : Terus kenapa bisa MS hanya mampu untuk menuliskan yang diketahui dan penyelesaiannya dituliskan secara asal - asalan?
SR-703 : Seperti yang saya tuliskan dalam komentar, mungkin MS tidak paham konsep karena dia saja tidak mampu untuk memisalkan model soal tersebut

Berdasarkan Transkrip 7 tersebut subjek mampu menjelaskan dengan baik define yang ada pada soal serta menggunakan semua tipe pertanyaan (deklaratif, prosedural, dan kondisional) dengan posisi yang tepat (SR-702). Maka dapat disimpulkan bahwa subjek berada pada level 2.

Hal ini menguatkan bahwa ternyata kemampuan akademik bukan merupakan hal yang utama dalam perkembangan pengetahuan konten, tetapi ada faktor lain misalnya pengalaman dan pelatihan. Hal ini sesuai dengan pendapat Martin (2008) bahwa gelar di bidang pelajaran membantu calon guru di kelas. Studi ini menunjukkan bahwa pengetahuan konten dari satu jurusan adalah bukan satu-satunya hal yang dibutuhkan untuk mengajar siswa.

\section{Conclusion}

Secara keseluruhan pada kelompok subjek dengan kemampuan akademik sangat baik, sedang dan rendah secara keseluruhan, dalam memulai kegiatan pembelajaran Sebagian besar subjek tidak menyampaikan tujuan pembelajaran secara detail. Berdasarkan RPP, tujuan pembelajaran yang disusun oleh subjek sudah jelas dan sesuai dengan kurikulum. Subjek juga memiliki pengetahuan terhadap konten materi yang akan diajarkan yaitu mengenai bentuk aljabar, mengubah soal cerita kedalam bentuk matematika. Subjek menerapkan strategi pembelajaran yang mendukung ketercapaian tujuan pembelajaran dan menggunakan strategi yang berbeda-beda. Dalam kegiatan pembelajaran subjek memberikan pertanyaan untuk menyelidiki kesulitan siswa khususnya ketika sedang menjelaskan penyelesaian soal tentang persamaan dan pertidaksamaan linear satu varaibel. Subjek juga mengintegrasikan materi pelajaran dengan materi lain yang dapat mendukung pemahaman siswa. Dari uraian diatas terlihat bahwa secara keseluruhan dalam aspek pedagogical knowledge, sebagian besar poin CoRe terpenuhi baik subjek dengan kemampuan tinggi, sedang dan rendah. Untuk aspek content knowledge yang dimiliki oleh subjek dengan indeks prestasi 3.50 - 4.00 berada pada level 1, kemudian indeks prestasi 3.00 - 3.50 berada pada level 0 serta indeks prestasi yang kurang dari 3.00 berada pada level 2. Pengetahuan konten pedagogik dari seseorang tidak hanya dipengaruhi oleh kemampuan akademiknya, tetapi dipengaruhi juga oleh pengalaman dan pelatihan tentang profesionalisme dan kemampuan pedagogis yang pernah diikuti. 


\section{References}

Anwar, Y., Rustaman, N. Y., Widodo, A., \& Redjeki, S. (2016). Perkembangan kemampuan pedagogical content knowledg e(pck) calon guru biologi pada pendekatan konkuren. Cakrawala Pendidikan, (3), Hal. 350

Aminah, N. (2013). Analisis kemampuan pedagogik dan self confidence calon guru matematika dalam menghadapi praktek pengalaman lapangan. Jurnal Euchid, 1(1), 55- 59.

Fuadi, T. M., A., \& Irfan, A. (2018). Analisis Pedagogical Content Knowledge Mahasiswa Calon Guru Pendidikan Matematika. (Jurnal Pendidikan Matematika)Vol. 7 No. 2

Iriani, A. \& Wulandari, M. R., (2018). Pengembangan modul pelatihan pedagogical content knowledge (pck) dalam meningkatkan kompetensi profesional dan kompetensi pedagogik guru matematika SMP. Kelola: Jurnal Manajemen Pendidikan, 5(2), 177-189.

Maryati, I. (2018). Penerapan model pembelajaran berbasis masalah pada materi pola bilangan di kelas vii sekolah menengah pertama. Jurnal Mosharafa Vol. 7 No. 1

Maryono. (2016). Profil pedagogical content knowledge (pck) mahasiswa calon guru matematika ditinjau dari kemampuan akademiknya Jurnal Review Pembelajaran Matematika Vol. 1 No. 1 Hal. 1-2

Miles \& Huberman. Qualitative Data Analysis: An Expended Sourcebook (3rd ed.),

Martin, F. (2008). Knowledge bases for effective teaching: Beginning teachers' developmentas teachers of primary geography. International Research in Geographical and Environmental Education, 17(1), 13-39.

Purwoko R.Y. (2017). Analisis kemampuan content knowledge mahasiswa calon guru matematika pada praktek pembelajaran mikro. Jurnal Pendidikan Surya Edukasi (JPSE), Vol. 3 No. 1 Hal. 57

Rosyid, A. (2016). Technological pedagogical content knowledge: sebuah kerangka pengetahuan bagi guru indonesia di era mea. In Prosiding Seminar Nasional Inovasi Pendidikan (pp. 446-454).

Loughran, J., Berry, A., \& Mulhall, P. (2016). Understanding and developing science teachers' pedagogical content knowledge (2nd ed.) Rotterdam: Sense Publisher.

Margiyono, I., \& Mampouw, H. L. (2011). Deskripsi Pedagogical Content Knowledge Guru pada Bahasan tentang Bilangan Rasional. Proceeding, 978-979-16353-7-0, p-13:1-12.

Santosa, M. G. W., Kusumaningsih, W., \& Endahwuri, D. (2019). Profil Pedagogical Content Knowledge (PCK) Calon Guru Matematika dalam Kesiapan Mengajar. Jurnal Matematika dan Matematika Vol. 1 No. 5 Hal. 186

Uyun, Q. (2019). Analisis Technological Pedagogical Content Knowledge mahasiswa calon guru matematika (Doctoral dissertation, UIN Sunan Gunung Djati Bandung). 